GRASAS Y ACEITES 68 (4)

October-December 2017, e218

ISSN-L: 0017-3495

doi: http://dx.doi.org/10.3989/gya.0442171

\title{
Chemical composition and oxidative stability of jussara (Euterpe edulis M.) oil extracted by cold and hot mechanical pressing
}

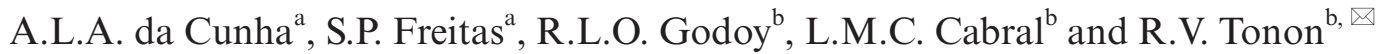 \\ ${ }^{a}$ Escola de Química, Universidade Federal do Rio de Janeiro. Av. Athos da Silveira Ramos, 149, 21941-909, Rio de Janeiro, \\ RJ, Brazil. \\ ${ }^{b}$ Embrapa Agroindústria de Alimentos. Av. das Américas, 29501, 23020-470, Rio de Janeiro, RJ, Brazil. \\ ${ }^{\square}$ Corresponding author: renata.tonon@embrapa.br
}

Submitted: 09 April 2017; Accepted: 11 July 2017

SUMMARY: The aim of this work was to evaluate the effect of mechanical pressing on jussara oil yield, oxidative stability and carotenoid profile with or without heat application. Firstly, jussara pulp was centrifuged for juice extraction, and the resulting cake was dried until reaching $10 \%$ moisture content. Then, oil extraction was performed in an expeller press at $25^{\circ} \mathrm{C}$ (cold pressing) and at $50{ }^{\circ} \mathrm{C}$ (hot pressing). The process performance was evaluated by the oil yield, and the crude jussara oil was characterized for fatty acid composition, acid value, carotenoid profile and oxidative stability. Jussara oil contained $74 \%$ unsaturated fatty acids, mainly oleic and linoleic acids ( $48 \%$ and $24 \%$, respectively). The oil yield was almost twice as high for the hot process as compared to the cold one. Additionally, hot pressing resulted in $25 \%$ higher total carotenoid content as compared to cold pressing, with $\beta$-carotene as the most abundant one. Hot and cold pressing showed no difference in oil oxidative stability and fatty acid composition.

KEYWORDS: Carotenoids; Euterpe edulis; Extraction; Fatty acid profile; Oxidative stability

RESUMEN: Composición química y estabilidad oxidativa del aceite de jussara (Euterpe edulis M.) extraído mediante prensado mecánico en frío y en caliente. El objetivo de este estudio fue evaluar el efecto del calor sobre el rendimiento del aceite, la estabilidad oxidativa y el perfil de carotenoides del aceite de Jussara extraído por prensado mecánico. En primer lugar, se centrifugó la pulpa de jussara para la extracción del zumo, y la torta resultante se secó para alcanzar el contenido de humedad de $10 \%$. Posteriormente, la extracción del aceite se realizó en una prensa a $25^{\circ} \mathrm{C}$ (prensado en frío) y a $50{ }^{\circ} \mathrm{C}$ (prensado en caliente). El desarrollo del proceso fue evaluado mediante el rendimiento de aceite y en bruto y éste se caracterizó mediante la composición en ácidos grasos, índice de acidez, perfil de carotenoides y la estabilidad oxidativa. El aceite de jussara presentó un $74 \%$ de ácidos grasos insaturados, principalmente ácidos oleico y linoleico ( $48 \%$ y $24 \%$, respectivamente). El rendimiento del aceite para el proceso en caliente fue casi el doble, en comparación con el proceso en frío. Además, el prensado en caliente mostró un contenido total de carotenoides $25 \%$ mayor en comparación con el prensado en frío, siendo el $\beta$-caroteno, el carotenoide más abundante. Las prensas en calientes y en frío no mostraron diferencias en la estabilidad oxidativa del aceite ni en la composición de ácidos grasos.

PALABRAS CLAVE: Carotenoides; Estabilidad oxidativa; Euterpe edulis; Extracción; Perfil de ácidos grasos

ORCID ID: da Cunha ALA http://orcid.org/0000-0001-6056-8122, Freitas SP http://orcid.org/0000-0003-1490-9883, Godoy RLO http://orcid.org/0000-0002-7506-8240, Cabral LMC http://orcid.org/0000-0003-2513-0381, Tonon RV http://orcid.org/0000-0002-2891-2760

Citation/Cómo citar este artículo: da Cunha ALA, Freitas SP, Godoy RLO, Cabral LMC. Tonon RV. 2017. Chemical composition and oxidative stability of jussara (Euterpe edulis M.) oil extracted by cold and hot mechanical pressing. Grasas Aceites 68 (4), e218. http://dx.doi.org/10.3989/gya.0442171

Copyright: (C2017 CSIC. This is an open-access article distributed under the terms of the Creative Commons Attribution (CC-by) Spain 3.0 License. 


\section{INTRODUCTION}

The Euterpe edulis palm tree belongs to the Arecaceae family and provides a fruit, known as jussara, which is similar to the Euterpe oleraceae fruit, the Amazonian açai. Although being widely distributed in Brazil, jussara is considerably less known and less consumed than açai (De Brito et al., 2007). It is a fruit native to the Atlantic Forest which is being threatened with extinction due to indiscriminate palm heart extraction. Thus, management of the fruits aiming to obtain new products is considered an important strategy to preserve the species.

The centrifugation or filtration of jussara pulp, usually applied as a pre-treatment in jussara processing, results in a clarified juice and a cake. This cake is a by-product which contains significant amounts of fiber, phenolic compounds and unsaturated fatty acid-rich oil and therefore, represents a valuable residue, which can become a potential raw material for the recovery of vegetable oil and bioactive ingredients.

Açai oil has been recently characterized by some authors, who found a composition of around $73 \%$ unsaturated fatty acids and $27 \%$ saturated fatty acids, being mainly composed of oleic acid $(\mathrm{C} 18: 1)$, and in minor proportions, palmitic and linoleic acids (C16:0 and C18:2, respectively) (Batista et al., 2016; Rufino et al., 2011). Jussara oil properties were evaluated by Borges et al. (2011), which observed fatty acids composition similar to açai oil. However, the carotenoid composition and oxidative stability, which are important quality factors for edible oils, were never reported for this oil.

Therefore, the objective of this work was to evaluate the fatty acid composition, acid value, carotenoid profile and oxidative stability of jussara oil, as affected by heat during extraction by mechanical pressing. The oil was obtained at room temperature (cold pressing) or at $50{ }^{\circ} \mathrm{C}$ (hot pressing). Process yield and extraction efficiency were also evaluated.

\section{MATERIALS AND METHODS}

\subsection{Materials}

Frozen jussara pulp was kindly donated by Juçaí (Serrinha do Alambari, RJ, Brazil). The moisture content in the raw-pulp was determined gravimetrically in a vacuum oven SP-104/12 (SPLabor, Presidente Prudente, Brazil) (method 969.38b, A.O.A.C., 2000), and oil content was determined with a Soxhlet apparatus Q308G22 (Quimis, Diadema, Brazil) using petroleum-ether $(99 \%$ purity, lot 1109120R, Tedia, Brazil) for extraction (method 920.39c, A.O.A.C., 2000).

\subsection{Oil extraction}

For oil extraction, the pulp was thawed and centrifuged in a SIZE 2 centrifuge (International Equipment Company, Chattanooga, USA), at $406 \times \mathrm{g}$. The resulting cake was dried in a tray dryer at $60{ }^{\circ} \mathrm{C}$, until reaching $10 \%$ moisture content. Then, oil extraction was performed by feeding the dried cake into a CA59G expeller press (Oekotec, Nordrhein-Westfalen, Germany), operating at $25^{\circ} \mathrm{C}$ (cold pressing) or at $50{ }^{\circ} \mathrm{C}$ (hot pressing). The jussara cake oil was stored at $-20^{\circ} \mathrm{C}$ until analysis.

Mechanical extraction performance was evaluated by the oil extraction yield (EY) and oil extraction efficiency (EE), according to Equations (1) and (2).

$$
\begin{aligned}
& E Y(\%)=\frac{\text { Mass of extracted oil }(g)}{\text { Mass of dried cake }(g)} \times 100 \\
& E E(\%)=\frac{\text { Mass of extracted oil }(g)}{\text { Mass of total oil }(g)} \times 100
\end{aligned}
$$

\subsection{Oil characterization}

Fatty acid composition. The methyl esters were prepared according to Hartman and Lago (1973) and the fatty acid profile was analyzed by gas chromatography in Agilent 7890 equipment (Agilent Technologies, Santa Clara, CA), fitted with a HP-FFAP capillary column $(25 \mathrm{~m} \times 0.2 \mathrm{~mm} \times$ $0.30 \mathrm{~m}$ ). Initial column temperature was set at $150{ }^{\circ} \mathrm{C}$ and held for $1 \mathrm{~min}$, increased to $180^{\circ} \mathrm{C}$ at $30{ }^{\circ} \mathrm{C} / \mathrm{min}$, further increased to $200^{\circ} \mathrm{C}$ at $20^{\circ} \mathrm{C} / \mathrm{min}$ and finally increased to $230{ }^{\circ} \mathrm{C}$ at $3{ }^{\circ} \mathrm{C} / \mathrm{min}$ and was held for $10 \mathrm{~min}$. Initial pressure was set at $15 \mathrm{psi}$ and held for $10 \mathrm{~min}$, increased to $25 \mathrm{psi}$ at $5 \mathrm{psi} /$ min and was held at 25 psi for 11 min. $1.0 \mu \mathrm{L}$ of sample was added to an injector operating at $250{ }^{\circ} \mathrm{C}$ and split mode (1:50). FID detector was kept at 280 ${ }^{\circ} \mathrm{C}$. Identification of FAME was based on the comparison of retention times with those of Nu-chek standards and quantification was done by internal normalization.

Acid value. The acid value was determined by titration, according to the method Cd3d-63 of A.O.C.S. (2012). Results were expressed in $\mathrm{mg} / \mathrm{g}$ $\mathrm{KOH}$ or in $\%$ oleic acid.

Carotenoid profile. Total carotenoid content and profiles were determined according to Kimura and Rodriguez-Amaya (2002) and Rodriguez-Amaya (2001), respectively.

Total carotenoid was determined using a spectrophotometer UV-1800 (Shimadzu Corporation, Kyoto, Japan) at $450 \mathrm{~nm}$. 
The carotenoid profile was analyzed by HPLC W600 (Waters, Milford, EUA) fitted with an automatic injector 717 Plus using a YMC (Waters ${ }^{\circledR}$ ) C30 column and a photodiode array W26996 detector at $450 \mathrm{~nm}$. The oven temperature was set at $35^{\circ} \mathrm{C}$. The flow rate of the mobile phase was $0.8 \mathrm{~mL} / \mathrm{min}$, and the injection volume was $15 \mu \mathrm{L}$ for both the standard and sample extracts. The mobile phase consisted of methanol (A): methyl-terc-butyl ether (B). A gradient elution was employed with $80 \mathrm{~mL}$ $\mathrm{A} / 20 \mathrm{~mL} \mathrm{~B}, 0.0-0.5 \mathrm{~min} ; 75 \mathrm{~mL} \mathrm{~A} / 25 \mathrm{~mL} \mathrm{~B}, 0.5-$ $15.0 \mathrm{~min} ; 15 \mathrm{~mL} \mathrm{~A} / 85 \mathrm{~mL} \mathrm{~B}, 15.0-15.5 \mathrm{~min} ; 10 \mathrm{~mL}$ $\mathrm{A} / 90 \mathrm{~mL} \mathrm{~B}, 15.5-16.5 \mathrm{~min}$; and finally, $80 \mathrm{~mL} \mathrm{~A} / 20$ $\mathrm{mL} \mathrm{B}$, until $28 \mathrm{~min}$ had passed. Carotenoids were identified based on their retention times and UV/ Vis absorption spectra, which were compared to the retention times of the standard carotenoids.

Oxidative stability. Oxidative stability was measured in Rancimat 743 equipment (Metrohm AG, Herisau, Switzerland) and the results were expressed as the Induction Period (IP). Three grams of each sample, in triplicate, were subjected to accelerated oxidation at $110^{\circ} \mathrm{C}$ with an air flow of $10 \mathrm{~L} / \mathrm{h}$.

Statistical analysis. Results were obtained in triplicate and statistically analyzed using the software XLStat (Addinsoft, Paris, France). Mean difference analysis was performed using Tukey's test at $p \leq 0.05$.

\section{RESULTS AND DISCUSSION}

\subsection{Drying and oil extraction}

Jussara raw-cake presented an initial moisture content of $69.8 \%$, which was reduced to about $10 \%$ after drying under convective air flow at $60{ }^{\circ} \mathrm{C}$. This water content was selected in preliminary tests with the aim of achieving the highest oil recovery by mechanical pressing. Lower moisture content could lead to oil retention in the cake pores; while higher moisture content could lead to an undesirable reduction in friction in the expeller and consequently to a non-pressed cake.

Figure 1 shows the oil extraction yield and extraction efficiency achieved with the cold and hot mechanical pressing of jussara cake. The cake subjected to hot pressing showed extraction yield and extraction efficiency values of approximately 20 and $60 \%$, respectively, twice as high as the values observed for the cold-pressed cake, which indicates that heating may have promoted cell breakdown, making oil recovery easier. According to Paula et al. (2015) and Savoire, Lanoisellé and Vorobiev et al. (2013), temperature is a parameter that affects the pressing performance in several ways. The increase in temperature causes a decrease in oil viscosity, favoring the oil flow, besides altering the cellular structure and plasticity of the raw material. However, although improving the oil yield, the use of higher temperatures can also negatively affect the

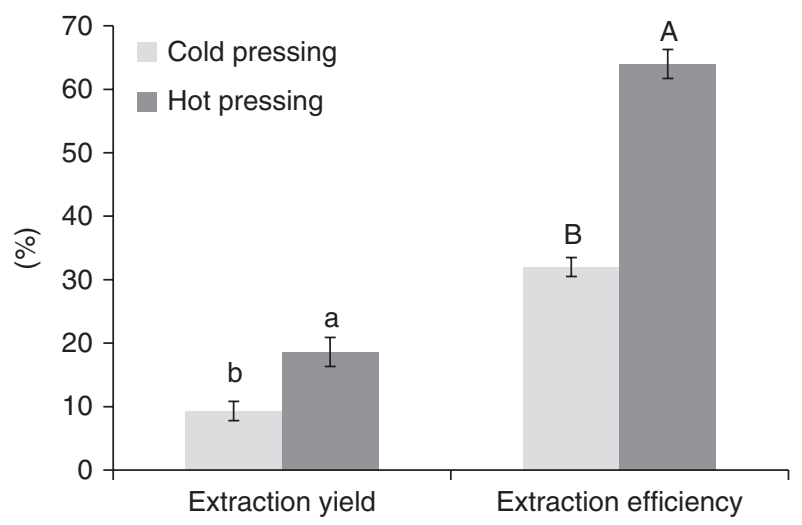

FIGURE 1. Oil yield and extraction efficiency of jussara oil obtained by mechanical pressing (different letters indicate significant difference between the extraction methods at $\mathrm{p} \leq 0.05$ ).

oil quality, since it can accelerate undesirable reactions such as lipid oxidation and degradation of bioactive compounds.

Similar behavior was reported by Tambunan et al. (2012) in the extraction of Jatropha seed oil. The authors used different temperatures (ambient, $50{ }^{\circ} \mathrm{C}, 60{ }^{\circ} \mathrm{C}$ and $80{ }^{\circ} \mathrm{C}$ ) and observed a significant increase in oil yield and extraction efficiency when temperature was increased up to $60{ }^{\circ} \mathrm{C}$, which was mainly attributed to the lower oil viscosity. The use of temperatures above $60{ }^{\circ} \mathrm{C}$, however, did not significantly affect these parameters.

Although solvent extraction using hexane has been widely applied in the oil industry, resulting in higher oil yields, the low sustainability of this process, together with issues associated to air pollution, toxicity and consumer health, are leading to the search for alternative green solvents and processes for oil extraction (Kumar et al., 2017). In this sense, expeller pressing and centrifugation have been highlighted from the ecological point of view, and considered suitable for edible oil production with no need for additional refining. Pre-treatments such as enzymatic treatment and/or different kinds of drying before extraction can also be suggested in order to improve oil recovery, as studied by Santana et al. (2015).

\subsection{Oil characterization}

Fatty acid composition. Table 1 shows the fatty acid composition of jussara oil extracted by cold and hot mechanical pressing. The oils extracted by both processes did not differ in their fatty acid composition. Jussara oil presented $74 \%$ unsaturated fatty acids, mainly oleic (C18:1) and linoleic (C18:2) acids (48\% and $24 \%$, respectively), in addition to $24 \%$ palmitic acid (C16:0). These values are similar to those reported by Borges et al. (2011) in the lipid fraction of jussara fruits collected in five different experimental stations and those reported by Nascimento et al. (2008) in açai oil. 
TABLE 1. Fatty acid composition of jussara oil extracted by cold and hot mechanical pressing

\begin{tabular}{lcc}
\hline & \multicolumn{2}{c}{ Extraction methods } \\
\cline { 2 - 3 } Fatty acids & Cold pressing (\%) & Hot pressing (\%) \\
\hline C16:0 & 23.75 & 23.85 \\
C16:1 & 1.29 & 1.30 \\
C18:0 & 2.27 & 2.25 \\
C18:1 & 47.64 & 47.62 \\
C18:2 & 24.15 & 24.09 \\
C18:3 & 0.90 & 0.90 \\
PUFA/SFA* & 0.96 & 0.96 \\
\hline
\end{tabular}

"PUFA/SFA = Polyunsaturated/Saturated ratio.

Schulz et al. (2015) also reported oleic acid as the main fatty acid found in juçara fruit pulp (35-42\% of total fatty acids), followed by palmitic and linoleic acids (25-30\%), while stearic, palmitoleic and alpha-linolenic acids were present in trace amounts. According to the authors, there was an increase in monounsaturated and polyunsaturated fatty acid contents during ripening.

Rufino et al. (2011) evaluated the fatty acid composition of 'BRS-Pará' açai fruit pulp and verified that it was composed of $27 \%$ saturated, $62 \%$ monounsaturated and $11 \%$ polyunsaturated fatty acids (PUFAs), indicating that the jussara oil obtained in the present work was richer in PUFAs, mainly C18:2.

In a recent study, Batista et al. (2016) evaluated the fatty acid contents of açai oil extracted by supercritical $\mathrm{CO}_{2}$ at different temperatures and pressures. The authors verified that the amount of saturated fatty acids varied from 26 to $99 \%$, and the monounsaturated fatty acids varied from 0.3 to $70 \%$, while polyunsaturated fatty acids $(12-15 \%)$ were only found in the oil extracted under specific conditions $\left(50{ }^{\circ} \mathrm{C} / 350\right.$ bar, $60{ }^{\circ} \mathrm{C} / 190$ bar and $70{ }^{\circ} \mathrm{C} / 220$ bar). This large variation could be attributed to changes in the solubility of the fatty acids promoted by temperature and pressure in the case of supercritical $\mathrm{CO}_{2}$ extraction.

Regarding the polyunsaturated/saturated ratio (PUFA/SAT), the oils obtained by both processes showed the same ratio of 0.96 . This value was lower than those observed for cold pressed oils from almond (3.19), Brazil nut (1.11), hazelnut (1.29) and pecan (2.11) (Castelo-Branco et al., 2016). However, it was higher than the value calculated for açai oil (0.41), based on the composition reported by Rufino et al (2011). The higher the PUFA/SAT ratio, the lower the oxidative stability of edible oils is. However, in the case of non-refined oils obtained from fruits, additional factors such as the presence of antioxidant compounds should be considered for the estimation of oxidative stability, since they can protect the oils against oxidation (Chen et al.,
TABLE 2. Carotenoid profile of jussara oil extracted by cold and hot mechanical pressing.

\begin{tabular}{lcc}
\hline & \multicolumn{2}{c}{ Extraction methods } \\
\cline { 2 - 3 } Carotenoids & $\begin{array}{c}\text { Cold pressing } \\
(\mu \mathrm{g} / \mathrm{mL})\end{array}$ & $\begin{array}{c}\text { Hot pressing } \\
(\mu \mathrm{g} / \mathrm{mL})\end{array}$ \\
\hline Lutein $(\mu \mathrm{g} / \mathrm{mL})$ & $16.36 \pm 3.85^{\mathrm{a}}$ & $23.53 \pm 3.49^{\mathrm{a}}$ \\
$\alpha$-Carotene $(\mu \mathrm{g} / \mathrm{mL})$ & $14.23 \pm 0.44^{\mathrm{b}}$ & $17.30 \pm 0.64^{\mathrm{a}}$ \\
$\beta$-Carotene $(\mu \mathrm{g} / \mathrm{mL})$ & $95.81 \pm 3.01^{\mathrm{b}}$ & $116.61 \pm 3.74^{\mathrm{a}}$ \\
13-cis- $\beta$-Carotene $(\mu \mathrm{g} / \mathrm{mL})$ & $3.67 \pm 0.19^{\mathrm{b}}$ & $4.38 \pm 0.52^{\mathrm{a}}$ \\
9-cis- $\beta$-Carotene $(\mu \mathrm{g} / \mathrm{mL})$ & $12.86 \pm 0.15^{\mathrm{b}}$ & $15.62 \pm 0.78^{\mathrm{a}}$ \\
Total carotenoids $(\mu \mathrm{g} / \mathrm{mL})$ & $151.78 \pm 7.22^{\mathrm{b}}$ & $190.12 \pm 6.64^{\mathrm{a}}$ \\
\hline
\end{tabular}

Different letters indicate significant difference between the extraction methods at $\mathrm{p} \leq 0.05$.

2011), which is the case of carotenoids in jussara oil. Moreover, according to Veldink et al. (2007), dietary intake of PUFAs decreases the risk of developing amyotrophic lateral sclerosis.

Acid value. Cold and hot pressing resulted in oils with acid values of $4.26 \pm 0.16 \mathrm{mg} \mathrm{KOH} / \mathrm{g}$ $(2.68 \pm 0.10 \%$ oleic acid) and $4.29 \pm 0.11 \mathrm{mg} \mathrm{KOH} / \mathrm{g}$ $(2.70 \pm 0.07 \%$ oleic acid), respectively. These results are slightly above the limit accepted by Brazilian law for pressed and crude oils (BRASIL, 2005), which is $4 \mathrm{mg} \mathrm{KOH} / \mathrm{g}$. The high acid value found in jussara oil may be attributed to the possible presence of endogenous and exogenous enzymes that promote a partial hydrolysis of triglycerides immediately after the fruit harvest and, particularly, during jussara pulp processing. In order to reduce this acid value, one alternative could be to subject the fruit to a step of enzyme inactivation with steam immediately after harvest, which is the procedure generally adopted before palm oil extraction (Wicke et al., 2008).

Ribeiro et al. (2012b) found an acid value of $5.44 \mathrm{mg} \mathrm{KOH} / \mathrm{g}$ in pequi oil extracted in an expeller press and observed that this value increased to 6.06 $\mathrm{mg} \mathrm{KOH} / \mathrm{g}$ after 180 days of storage. Aquino et al. (2012) reported that the crude buriti oil had an acid value of $4.27 \%$ oleic acid, while in the refined oil this value was reduced to $0.21 \%$. These values were higher than those observed for jussara oil in the present work and confirm the fact that the enzymes present in fruits can contribute to the hydrolysis of triglycerides in oils extracted from this type of matrix, increasing their acid values.

Carotenoid profile. The carotenoids identified in jussara oil and their respective quantifications, as well as the total carotenoid content, are presented in Table 2.

The most abundant carotenoid in jussara oil was $\beta$-carotene, representing $66-67 \%$ of all the identified carotenoids. The oil extracted at $50{ }^{\circ} \mathrm{C}$ was richer in carotenoids when compared to the oil extracted by cold pressing, showing higher amounts of all the identified carotenoids. This can be attributed to the 
higher solubility of carotenoids with increasing oil temperatures (Yuan et al., 2008).

The carotenoid content of jussara oil was higher when compared to oils extracted from some fruit seeds, such as grape, guava, melon, passion fruit, pumpkin, soursop and tomato, which varied from 4.4 to $11.9 \mathrm{mg} / \mathrm{g}$ (Da Silva and Jorge, 2014). Nunes et al. (2015) observed higher carotenoid contents $(378 \mu \mathrm{g} / \mathrm{g})$ in crude macauba oil extracted by mechanical pressing, and verified that this value was drastically reduced to $9 \mathrm{mg} / \mathrm{g}$ during refining. Soltana et al. (2016) extracted the oil from the achenes of Ficus carica and observed a $\beta$-carotene content of $81.08 \mathrm{mg} / \mathrm{g}$.

Ribeiro et al. (2012a) and Speranza et al. (2016) found much higher values of total carotenoids for commercial crude buriti oil (1800 and $782 \mathrm{mg} / \mathrm{kg}$ oil, respectively), which is extracted from an Amazonian fruit known as a good source of these pigments. Pequi oil extracted by expeller pressing showed a total carotenoid content of $24.96 \mathrm{mg} / 100 \mathrm{~g}$ (or 249.6 $\mathrm{mg} / \mathrm{kg}$ ), while extraction using ethyl ether and acetone resulted in even higher values (38.95 and 42.66 $\mathrm{mg} / 100 \mathrm{~g}$, respectively). In this case, $\beta$-carotene was also the main carotenoid identified (Ribeiro et al., 2012b).

The presence of carotenoids in edible oils is considered a positive characteristic, mainly due to their antioxidant properties, which can have functions both in food technology, by increasing oxidative stability, as in human health. Miranda-Vilela et al. (2014) evaluated the effect of a carotenoidrich oil (pequi oil), instead of vitamins $\mathrm{C}$ and $\mathrm{E}$, on the reduction of chemotherapy adverse effects to normal cells in Ehrlich solid tumor-bearing mice. The authors observed that the treatments with pequi oil provided before tumor inoculation or in continuous and concurrent administration with doxorubicin were more effective in containing tumor growth, in addition to increasing immunity and reducing the adverse side effects associated with oxidative damage to normal cells.

Oxidative stability. The induction periods (IP) for the oils extracted by cold and hot pressing were 9.90 \pm 0.69 and $9.94 \pm 0.39$ hours, respectively. These values are higher than those recommended for refined oils (BRASIL, 2005).

Santana et al. (2015), studied the oil extraction from avocado pulp by cold pressing and obtained an IP of 7.03 hours, using the same conditions of the present work $\left(110^{\circ} \mathrm{C}\right.$ and a flow rate of $\left.10 \mathrm{~L} / \mathrm{h}\right)$ when the pulp was oven dried at $60^{\circ} \mathrm{C}$ before extraction. The authors observed that when the pulp was oven dried at $45^{\circ} \mathrm{C}$ and subjected to an enzymatic treatment before extraction, the oil had higher oxidative stability (IP of 10.78 hours). Furthermore, when the pulp was microwave-dried, the oxidative stability was considerably higher, reaching an IP of 20.84 hours. These results suggest that the pre-treatment of the material before extraction is an alternative that should be carefully evaluated, since it can significantly improve the properties and stability of the oil.

Compared to other vegetable oils extracted by cold pressing such as almond, Brazil nut, hazelnut and macadamia (Castelo-Branco et al., 2016), jussara oil showed higher oxidative stability, with longer induction periods. This can be related to the lower PUFA/SFA ratio in jussara oil as compared to the above-mentioned ones. According to Méndez et al. (1996), the PUFA/SFA ratio is a measure of the extent of oil polyunsaturation and, consequently, of its tendency to undergo autoxidation.

The high oxidative stability of jussara oil can also be attributed to the carotenoids present in its composition, which are considered natural antioxidants. These compounds prevent the autoxidation of oils and fats by providing their hydrogen to react with the free radicals formed in the initiation and propagation stages of autoxidation. Therefore, they prevent the formation of radicals in two ways: by scavenging them, or by promoting their decomposition (Young and Woodside, 2001).

\section{CONCLUSIONS}

Jussara oil extracted by hot and cold mechanical pressing was characterized as an unsaturated fatty acids-rich oil, mainly composed of oleic and linoleic acids. Extraction yield was twice as high for the process performed at $50{ }^{\circ} \mathrm{C}$ as compared to cold pressing. Jussara oil was also characterized as a carotenoid-rich oil, as compared to specialty oils from native and tropical Brazilian fruits, which are mainly composed of $\beta$-carotene. Regarding oxidative stability, it was considered more stable than these oils and this was related to its lower polyunsaturated/saturated ratio, which expresses the oil's tendency to undergo autoxidation.

\section{ACKNOWLEDGMENTS}

The authors are grateful to $\mathrm{CNPq}$ for the scholarship.

\section{REFERENCES}

A.O.A.C. Association of Official Analytical Chemists: Official Methods of Analysis. $17^{\text {th }}$ Edition. Gaithersburg, MD, USA, 2000

A.O.C.S. American Oil Chemists' Society. Official Methods and Recommended Practices of the American Oil Chemists' Society. 6th Edition. Champaign, IL, USA, 2012.

Aquino JS, Pessoa DCNP, Oliveira CEV, Cavalheiro JMO, Stamford TLM. 2012. Making cookies with buriti oil (Mauritia flexuosa L.): an alternative source of dietary vitamin A in school meals. Rev. Nutr. 25, 765-774. http:// dx.doi.org/10.1590/S1415-52732012000600008

Batista CCR, Oliveira MS, Araújo ME, Rodrigues AMC, Botelho JRS, Filho APSS, Machado NT, Junior RNC. 2016. Supercritical $\mathrm{CO}_{2}$ extraction of açaí (Euterpe oleracea) 
berry oil: Global yield, fatty acids, allelopathic activities, and determination of phenolic and anthocyanins total compounds in the residual pulp. J. Supercrit. Fluid. 107, 364 369. http://dx.doi.org/10.1016/j.supflu.2015.10.006

Borges GSC, Vieira FGK, Copetti C, Gonzaga LV, Zambiazi RC, Filho JM, Fett R. 2011. Chemical characterization, bioactive compounds, and antioxidant capacity of jussara (Euterpe edulis) fruit from the Atlantic Forest in southern Brazil. Food Res. Int. 44, 2128-2133. http://dx.doi. org/10.1016/j.foodres.2010.12.006

BRASIL. ANVISA, Resolução RDC n 270, de 22 de setembro de 2005. 2005. Regulamento técnico para óleos vegetais, gorduras vegetais e creme vegetal.

Castelo-Branco VN, Santana I, Di-Sarli VO, Freitas SP, Torres AG. 2016. Antioxidant capacity is a surrogate measure of the quality and stability of vegetable oils. Eur. J. Lipid Sci. Tech. 118, 224-235. https://doi.org/10.1002/ ejlt.201400299

Chen B, McClements DJ, Decker EA. 2011. Minor components in food oils: A critical review of their roles on lipid oxidation chemistry in bulk oils and emulsions. Crit. Rev. Food Sci. 51, 901-916. http://dx.doi.org/10.1080/10408398.2011. 606379

Da Silva, AC, Jorge N. 2014. Bioactive compounds of the lipid fractions of agro-industrial waste. Food Res. Int. 63, 493500. http://dx.doi.org/10.1016/j.foodres.2014.10.025

De Brito ES, De Araújo MCP, Alves RE, Carkeet CC, Clevidence B, Novotny J. 2007. Anthocyanins present in selected tropical fruits: Acerola, jambolão, jussara, and guarabiju. J. Agric. Food Chem. 55, 9389-9394. http:// dx.doi.org/10.1021/jf0715020

Hartman L., Lago RCA. 1973. Rapid preparation of fatty acid methyl esters. Lab. Pract. 22, 175-176.

Kimura M., Rodriguez-Amaya DB. 2002. A scheme for obtaining standards and HPLC quantification of leafy vegetable carotenoids. Food Chem. 78, 389-398. http://dx.doi. org/10.1016/S0308-8146(02)00203-0

Kumar SPJ, Prasad SR, Banerjee R, Agarwal DK, Kulkarni KS, Ramesh KV. 2017. Green solvents and technologies for oil extraction from oilseeds. Chem. Central J. 11, 1-9. http:// dx.doi.org/10.1186/s13065-017-0238-8

Méndez E., Sanhueza J., Speisky H., Valenzuela A. 1996. Validation of the Rancimat test for the assessment of the relative stability of fish oils. J. Am. Oil Chem. Soc. 73 , 1033-1037. http://dx.doi.org/10.1007/BF02523412

Miranda-Vilela AL, Grisolia CK, Longo JPF, Peixoto RCA, Almeida MC, Barbosa LCP, Rolla MM, Portilho FA, Estevanato LLC, Bocca AL, Báo SN, Lacava ZGM. 2014. Oil rich in carotenoids instead of vitamins $C$ and $E$ as a better option to reduce doxorubicin-induced damage to normal cells of Ehrlich tumor-bearing mice: hematologi$\mathrm{cal}$, toxicological and histopathological evaluations. $J$. Nutr. Biochem. 25, 1161-1176. https://doi.org/10.1016/j. jnutbio.2014.06.005

Nascimento RJS, Couri S, Antoniassi R, Freitas SP. 2008. Fatty acids composition of açaí pulp oil obtained by enzymatic technology and hexane. Rev. Bras. Frutic. 30, 498-502. http://dx.doi.org/10.1590/S0100-29452008000200040

Nunes AA, Favaro SP, Galvani F, Miranda CHB. 2015. Good practices of harvest and processing provide high quality Macauba pulp oil. Eur. J. Lipid Sci. Tech. 117, 2036-2043. http://dx.doi.org/10.1002/ejlt.201400577

Paula RM, Soares AG, Freitas SP. 2015. Volatile compounds in passion fruit seed oil (Passiflora setacea BRS Pérola do Cerrado e Passiflora alata BRS Doce Mel). Chem. Eng. Trans. 44, 103-108.
Ribeiro BD, Coelho MAZ, Barreto DW. 2012a. Production of concentrated natural beta-carotene from buriti (Mauritia vinifera) oil by enzymatic hydrolysis. Food Bioprod. Process. 90, 141-147. http://dx.doi.org/10.1016/j.fbp.2011.02.003

Ribeiro MC, Vilas-Boas EVB, Riul TR, Pantoja L, Marinho HA, dos Santos AS. 2012b. Influence of the extraction method and storage time on the physicochemical properties and carotenoid levels of pequi (Caryocar brasiliense Camb.) oil. Food Sci. Tech. 32, 386-392. http://dx.doi. org/10.1590/S0101-20612012005000053

Rodríguez-Amaya DB. 2001. A guide to carotenoid analysis in food. ILSI Press, Washington, DC (EUA).

Rufino MSM, Pérez-Jiménez J, Arranz S, Alves RE, de Brito ES, Oliveira MSP, Saura-Calixto F. 2011. Açaí (Euterpe oleraceae) 'BRS Pará': A tropical fruit source of antioxidant dietary fiber and high antioxidant capacity oil. Food Res. Int. 44, 2100-2106. http://dx.doi.org/10.1016/j. foodres.2010.09.011

Santana I., dos Reis LMF, Torres AG, Cabral LMC, Freitas SP. 2015. Avocado (Persea americana Mill.) oil produced by microwave drying and expeller pressing exhibits low acidity and high oxidative stability. Eur. J. Lipid Sci. Technol. 117, 999-1007. http://dx.doi.org/10.1002/ejlt.201400172

Savoire R, Lanoisellé JL, Vorobiev E. 2013. Mechanical continuous oil expression from oilseeds: A review. Food Bioprocess Technol. 6, 1-16. http://dx.doi.org/10.1007/ s11947-012-0947-x

Schulz M, Borges GSC, Gonzaga LV, Seraglio SKT, Olivo IS, Azevedo MS, Nehring P, Gois JS, Almeida TS, Vitali L, Spudeit DA, Micke GA, Borges DLG, Fett R. 2015. Chemical composition, bioactive compounds and antioxidant capacity of juçara fruit (Euterpe edulis Martius) during ripening. Food Res. Int. 77, 125-131. http://dx.doi. org/10.1016/j.foodres.2015.08.006

Soltana H, Tekaya M, Amri Z, El-Gharbi S, Nakbi A, Harzallah A, Mechri B, Hammami M. 2016. Characterization of fig achenes' oil of Ficus carica grown in Tunisia. Food Chem. 196, 1125-1130. http://dx.doi.org/10.1016/j. foodchem.2015.10.053

Speranza P, Falcão AO, Macedo JA, da Silva LHM, Rodrigues AMC, Macedo GA. 2016. Amazonian Buriti oil: chemical characterization and antioxidant potential. Grasas Aceites 37, 1-9. http://dx.doi.org/10.3989/gya.0622152

Tambunan AH, Situmorang JP, Silip JJ, Joelianingsih A, Araki T. 2012. Yield and physicochemical properties of mechanically extracted crude Jatropha curcas L. oil. Biomass Bioenerg. 43, 12-17. http://dx.doi.org/10.1016/j. biombioe.2012.04.004

Veldink JH, Kalmijn S, Groeneveld GJ, Wunderink W, Koster A, de Vries JHM., van der Luyt J, Wokke JH, van den Berg LH. 2007. Intake of polyunsaturated fatty acids and vitamin $E$ reduces the risk of developing amyotrophic lateral sclerosis. J. Neurol. Neurosurg. Psychiatry. 78, 367-371. http://dx.doi.org/10.1136/jnnp.2005.083378

Wicke B, Dornburg V, Junginger M, Faaij A. 2008. Different palm oil production systems for energy purposes and their greenhouse gas implications. Biomass Bioenerg. 32, 13221337. http://dx.doi.org/10.1016/j.biombioe.2008.04.001

Young IS, Woodside JV. 2001. Antioxidants in health and disease. J. Clin. Patholology 54, 176-186. http://dx.doi. org/10.1136/jcp.54.3.176

Yuan Y, Gao Y, Zhao J, Mao L. 2008. Characterization and stability evaluation of $\beta$-carotene nanoemulsions prepared by high pressure homogenization under various emulsifying conditions. Food Res. Int. 41, 61-68. http://dx.doi. org/10.1016/j.foodres.2007.09.006 